Review

\title{
Lymphoma Caused by Intestinal Microbiota
}

\section{Mitsuko L. Yamamoto and Robert H. Schiestl *}

Department of Pathology, Environmental Health and Radiation Oncology, University of California, Los Angeles, Schools of Medicine and Public Health, 10833 Le Conte Ave, Los Angeles, CA 90095, USA; E-Mail: m.l.yamamoto@gmail.com

* Author to whom correspondence should be addressed; E-Mail: rschiestl@ mednet.ucla.edu; Tel.: +1-310-267-2087.

Received: 17 June 2014; in revised form: 14 August 2014 / Accepted: 15 August 2014 / Published: 1 September 2014

\begin{abstract}
The intestinal microbiota and gut immune system must constantly communicate to maintain a balance between tolerance and activation: on the one hand, our immune system should protect us from pathogenic microbes and on the other hand, most of the millions of microbes in and on our body are innocuous symbionts and some can even be beneficial. Since there is such a close interaction between the immune system and the intestinal microbiota, it is not surprising that some lymphomas such as mucosal-associated lymphoid tissue (MALT) lymphoma have been shown to be caused by the presence of certain bacteria. Animal models played an important role in establishing causation and mechanism of bacteria-induced MALT lymphoma. In this review we discuss different ways that animal models have been applied to establish a link between the gut microbiota and lymphoma and how animal models have helped to elucidate mechanisms of microbiota-induced lymphoma. While there are not a plethora of studies demonstrating a connection between microbiota and lymphoma development, we believe that animal models are a system which can be exploited in the future to enhance our understanding of causation and improve prognosis and treatment of lymphoma.
\end{abstract}

Keywords: intestinal microbiota; inflammation; cancer; lymphoma; prevention 


\section{Introduction}

Lymphocytes play a key role in responding to microbial colonization by initiating an immune response leading to tolerance or activation. The majority of immunologically active cells belong to the mucosal-associated immune system and are constantly receiving signals from dendritic cells or other APCs which are sampling the intestines. Dysregulation can lead to inflammation-related diseases such as colitis and cancer, as reviewed in this issue. Tissues closely associated with bacterial exposure have been most easily identified as being affected by microbes such as colon cancer and gastric cancers [1] and in current issue) however intestinal health can alter extra-gastrointestinal tissues, having a systemic effect [2,3]. Animal models have played an essential role in understanding the importance of the gut microbiome in immune development and composition [4]. Animal models have also played a key role in solidifying the relationship between the microbiome and health and disease [5]. Techniques to manipulate animal gut composition have been studied and refined for over 50 years and continue to play an important role in clarifying this symbiotic and sometimes pathogenic relationship [6].

\section{Microbiota and Lymphoma in Animal Models}

There are two major ways that animal models have an advantage in studying the relationship between gut microbes and cancer. First, the mouse gut microbiome can be altered to be germ free, contain specific species of bacteria (gnotobiotic), or to have what is commonly called conventional microbiota, which is considered "normal" and generally unmonitored in genetically similar animals. Changing the microbiome allows us to study cause and effect relationship between the bacteria and body. Germfree animals have demonstrated the role of microbiota in inflammation, metabolism, and obesity $[5,7,8]$. Gnotobiotic models have helped to determine both causative species and mechanisms of colorectal cancer $[9,10]$. Second, animal models have been used to determine how genes may affect or be affected by different bacteria. These models can help us determine genetic susceptibility or resistance to different diseases depending on microbial exposure. For example polymorphisms in Dectin1 can influence susceptibility to colitis [11]. Alternatively, genetic models can help us determine which genes or pathways may be important in disease development or protection [12]. For example, Rag2-/- mice can develop H. hepaticus-induced cancer, however immune competent mice are protected due to a regulatory response leading to decreased inflammation [13]. Combining both a defined gut microbiota and genetic models can also give us important insights into mechanisms of gut-microbe interactions.

\subsection{Historical Data Indicating That Gut Microbes May Affect Mouse Phenotypes Such as Cancer and Lifespan}

While inbred mouse strains have helped to decrease variability among and within experiments, over time even these carefully maintained strains may acquire differences. Changes in phenotypes of research animals have been noted as early as 1966 in various fields from radiation to toxicology [14-18]. Internal factors such as genetic drift or spontaneous mutations can play a role in varying phenotypes of research animals [19,20]. Many environmental factors have also been postulated to contribute to changes in rodents including housing conditions, diet, and sterility [15,17,21]. 
Significant changes in lifespan or tumor incidence may have important consequences on experimental results. For example, over an 11 year period, percent survival of male F344 rats at 106 weeks decreased from $85.3 \%$ in experiments starting in 1971 to $62.5 \%$ in experiments starting in 1980-1981 [16]. In addition, leukemia incidence increased from $9.4 \%$ to $20.1 \%$ in male rats in experiments starting in 1972-1973 and 1980-1981, respectively [16]. Experiments using 3 Gy X-rays to induce myeloid leukemia show that $32.3 \%$ of mice developed the disease in 1956 while only $12.8 \%$ developed myeloid leukemia in 1964 [17]. While different environmental factors have been attributed to these changes, it is well known that animal husbandry protocols have also become more stringent, affecting animal microbial composition and health [22]. More recently, our lab has shown that in different vivariums, with different specific pathogen free (SPF) conditions, isogenic mice have altered lifespans and lymphoma latency periods [18,23]. This correlates to distinct microbiome profiles as determined by $16 \mathrm{~S}$ rRNA lengths. Therefore it is likely that the microbiome has at least a partial influence on animal health, including carcinogenesis.

\subsection{Animal Models of Mucosal-Associated Lymphoid Tissue (MALT) Lymphoma}

Mucosal-associated lymphoid tissue (MALT) lymphomas are thought to originate in the marginal zone and are strongly associated with the presence of Helicobacter [24,25]. Approximately 90\% of MALT lymphomas are associated with Helicobacter infection [26]. Elimination of Helicobacter leads to complete remission in approximately $80 \%$ of all cases [27]. While the association of $H$. pylori and MALT lymphoma was discovered in humans, the causative effect of Helicobacter in MALT lymphoma development, according to the Koch's Postulate, was demonstrated in animal models. A model of bacteria-induced MALT was first shown in mice by infection with $\mathrm{H}$. felis, a close relative to H. pylori. Twenty two weeks post-infection, $25 \%$ of infected mice had lymphoepithelial lesions while none of the non-infected animals did [28]. An H. pylori infection was first established in gerbils and showed an increase in gastritis and intestinal metaplasia [29]. Since then, H. pylori infections have been established in mouse models and have been used to examine mechanism by assessing transcription profiling [30] and disease progression and regression [31].

$H$. helmanii, found in both human and mice, also leads to MALT lymphoma which is preceded by inflammation and high endothelial venule-like vesicles, which are associated with lymphocyte recruitment and present in other chronic inflammatory conditions such as rheumatoid arthritis, and colitis [32]. The animal models of $H$. helmanii-induced lymphoma, however, seem to have varying results and may also involve host and bacterial factors [33]. The use of better defined bacteria, however, may improve consistency and development of MALT lymphoma for future studies [34].

Other bacteria such as Campylobacter jejuni, Borrelia bergdorferi, and Chlamidia psitacci may also play a role in lymphoma development, however these associations have only been shown in humans thus far [35]. Streptococcus bovis has been associated with hematopoietic malignancy in humans [36]. Therefore, animal models may provide valuable insight into microbe-associated lymphoma etiology, progression, and treatment. 


\subsection{Animal Models of Lymphoma and Effects of the Microbiome}

Animal models of cancer can also be useful in demonstrating a link between the microbiome and carcinogenesis. Cancer is a disease that is generally thought to occur in a multi-step process beginning with initiation, promotion, and finally progression. As the disease progresses, cells acquire "hallmarks of cancer" which include sustained proliferation, resistance to cell death, and metastasis [37]. Using animal cancer models such as p53-deficient mice, allows researchers to bypass some steps required for overt cancer saving time and animal numbers. ApcMin/+ mice, which spontaneously develop intestinal polyps, have been used to demonstrate that infection with Citrobacter rodentium or enterotoxin-producing Bacterioides fragilis can promote colon cancer [38,39]. A chemically induced model of liver cancer also showed that Helicobacter hepaticus infection promotes liver tumorigenesis [40].

Our lab has shown that mice deficient in the Ataxia telangiectasia mutated gene (Atm-/- mice), which display genetic instability and spontaneously develop a high incidence of thymic lymphoma [41,42], are sensitive to changes in microbial content [23]. We found that as Atm-/- mice moved to more sterile conditions, they began to live longer and have a decreased lymphoma penetrance $[18,23]$. Conversely, when they were moved to standard SPF conditions, their lifespan and lymphoma latency decreased. To test the effects of the gut microbiota more directly, we rederived mice into a restricted microbiota facility [43] and "conventionalized" mice by inoculating them with fecal samples from conventional SPF mice. Again, the "conventionalized" mice had shorter lifespans than the mice with a restricted flora [23]. These results indicated that microbes in the restricted, sterile facility had a protective effect in Atm-/- mice and/or the conventional microbiota had a more pathogenic effect. One microbe that was highly enriched in the restricted microbiome was Lactobacillus johnsonii. Inoculation with L. johnsonii in Atm-/- mice decreased measures of DNA damage, oxidative stress, and inflammation [23]. These results indicate that the gut microbiota can impact lymphomagenesis in Atm-/- mice. Other lymphoma or cancer models may also contribute to the growing body of evidence linking the microbiome to carcinogenesis.

\section{Mechanism of Microbiota-Induced Lymphomagenesis as Evidenced in Animal Models}

While there is not a plethora of animal models linking the microbiome to lymphoma development, there is a large amount of data indicating plausible mechanisms of microbiota-induced lymphomagenesis in animal models. Since the intestinal microbiota has been shown to influence the immune system directly and indirectly ([44,45] and in the current issue), there are several ways that the intestinal microbiota may affect lymphomagenesis in mice. Many of these mechanisms have been identified and shown in animal models.

\subsection{Microbiota Can Directly Initiate Lymphomagenesis}

Species of gut bacteria may directly cause the promotion or neutralization of mutagens and oxidative stress [46-54] leading to DNA damage and subsequent cancer or protection [55] From here on the reference No need to be shifted for one number see attached original. Faecal water samples from mice treated with pre- and probiotics showed different degrees of genotoxicity which correlated with tumorigenesis [55]. Bacteria can also directly interact with immune cells causing oxidative 
bursts [56] or necrosis [56], and with epithelial cells causing increased production of reactive oxygen

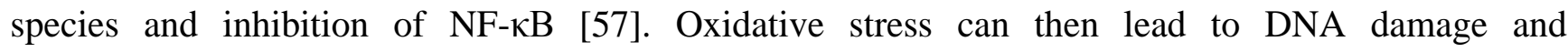
carcinogenesis [58-60]. $H$. pylori and $C$. jejuni have both been shown to increase oxidative stress [53,54]. Finally, bacteria can act as an antigen and stimulate chronic proliferation of immune cells. H. pylori is thought to cause lymphoma because of constant stimulation of antigen presentation leading to B cell expansion [31,61]. In humans, this is evident in the overrepresentation of certain $\mathrm{V}$ genes $[35,62]$. While the lymphocytes and microbes are generally separated by the epithelial barrier, bacteria, antigens, or metabolites cross the mucosal barrier through dendritic cells or M cells which are constantly sampling the lumen [63]. In addition to causing damage, bacteria can also help to neutralize mutagens and oxidative stress ([64], reviewed in [65]). The mutagens MNNG and DMH have been shown to be neutralized in rat colons by lactic acid bacteria.

\subsection{Microbiota Can Alter Immune Parameters to Affect Lymphomagenesis}

Species, or populations of gut bacteria may cause a change in immune response or immune parameters and affect lymphocytes. Intestinal immune cells are constantly sampling luminal content and deciding whether to elicit or suppress an immune response [44]. Animal studies have shown that both single species of bacteria as well as different bacterial compositions can have large impacts on immune parameters. For example, studies using germ-free mice established that intestinal microbiota are essential for normal immune system development [66-68]. Since lymphoma itself is a shift in immune cell types, it is not surprising that microbes may influence lymphomagenesis.

Several animal studies have shown that either a mixture of bacteria or single species may significantly affect immune cell population and activity [43,69-73]. For example, inoculation with segmented filamentous bacteria caused a change in $\mathrm{T}$ cell activity eliciting a range of responses including increases in IL-10, IL-17, and IFN- $\gamma$ [72]. In addition, inoculation of Sphingomonas yanoikuyae caused a systemic change in immune cell populations [43]. Bacterioides fragilis can induce a Th17 response in mice which was then shown to be required for tumorigenesis [39]. Bacteria can also directly alter inflammation-related pathways. Inoculation with common human commensal bacterium $B$. thetaiotaomicron, B. longum, or both resulted in an increase in TNF- $\alpha$ - and IFN- $\gamma$-associated pathways [74]. These studies indicate that gut microbes can affect the immune system which may impact lymphoma development.

Alternatively, distinct compositions of intestinal microbiota can differentially alter immune parameters [43,69,70] which may protect mice against cancerous cells. Mice with a restricted microbiota have increased cytotoxic $\mathrm{T}$ cells which leads to decreased levels of marginal zone $\mathrm{B}$ cells [69], invariant NKT $(i \mathrm{NKT})$ cells [70], and plasmacytic dendritic cells compared to mice with conventional flora [43]. Moreover, Wei et al. suggest that the activity of adoptively transferred cytotoxic CD8+ $\mathrm{T}$ cells can be increased if recipient mice are inoculated with donor microbial antigens [69]. It has also been shown that germ-free colorectal cancer rat models mount different responses to cancer induction compared to conventional mice including increased B cells, NK cells and cytotoxic T lymphocytes [75].

Conversely, some bacteria and bacterial products may have a beneficial effect. For example, lactic acid bacteria and specific recognition of Lactobacilli may protect against carcinogenesis $[76,77]$. 
Lactobacillus johnsonii in rat intestines has been shown to have a positive effect on oxidative stress and inflammation and prolongs the development of diabetes [78,79]. Lactic acid bacteria can also modify the immune system to prevent cancer in mouse tumor models ([80-82] (reviewed in [65,83]). In addition, butyrate, a short-chain fatty acid produced by bacterial fermentation of fiber on Treg cell specification and expansion $[84,85]$.

Whether microbes influence immune cells directly, indirectly, or a combination of both, increased lymphocyte proliferation can lead to a higher chance of aberrant DNA replication [86,87], particularly in some B lymphocytes which are innately vulnerable to genetic instability [88,89] and activation [90]. Oxidative stress caused by intestinal microbiota either directly [91] or indirectly through the immune system [92], can also affect carcinogenesis. Therefore, the microbiota can affect several pathways associated with lymphomagenesis $[93,94]$.

\section{Conclusions}

While there is evidence that the microbiome affects lymphomagenesis, particularly MALT lymphomas, there is a wide gap of knowledge to which animal models could provide valuable answers. Namely, which bacteria or bacterial products can cause, protect against, or increase risk of lymphoma development? With the exception of breast cancer, liver cancer, and lymphoma, systemic effects of intestinal bacteria on cancer have not been studied. Lymphomas are of particular interest because they circulate through the gastro-intestinal system as well as the rest of the body. The fact that more lymphomas are becoming associated with bacterial infections [95-97] and that antibiotic therapy can be effective $[95,97]$ underscores the need for more studies involving microbes and lymphoma.

There is overwhelming evidence that some intestinal bacteria are health beneficial like the Lactobacilli whereas some others are health detrimental like some of the Helicobacteraceae. It will be very important to determine the roles as health beneficial and detrimental of most intestinal bacteria and whether there are synergisms or antagonisms between them. Then one can design certain probiotics containing the health beneficial and certain antibiotics against the health detrimental bacteria.

\section{Author Contributions}

Mitsuko L. Yamamoto prepared the original draft, which was revised by all authors. All authors read and approved the final manuscript.

\section{Conflicts of Interest}

The authors declare no conflict of interest.

\section{References}

1. Compare, D.; Nardone, G. Contribution of gut microbiota to colonic and extracolonic cancer development. Dig. Dis. 2011, 29, 554-561.

2. Westbrook, A.M.; Wei, B.; Braun, J.; Schiestl, R.H. Intestinal mucosal inflammation leads to systemic genotoxicity in mice. Cancer Res. 2009, 69, 4827-4834. 
3. Westbrook, A.M.; Wei, B.; Braun, J.; Schiestl, R.H. Intestinal inflammation induces genotoxicity to extraintestinal tissues and cell types in mice. Int. J. Cancer 2011, 129, 1815-1825.

4. Umesaki, Y.; Setoyama, H. Structure of the intestinal flora responsible for development of the gut immune system in a rodent model. Microbes Infect. 2000, 2, 1343-1351.

5. Tlaskalova-Hogenova, H.; Stepankova, R.; Kozakova, H.; Hudcovic, T.; Vannucci, L.; Tuckova, L.; Rossmann, P.; Hrncir, T.; Kverka, M.; Zakostelska, Z.; et. al. The role of gut microbiota (commensal bacteria) and the mucosal barrier in the pathogenesis of inflammatory and autoimmune diseases and cancer: Contribution of germ-free and gnotobiotic animal models of human diseases. Cell Mol. Immunol. 2011, 8, 110-120.

6. Faith, J.J.; Rey, F.E.; O’Donnell, D.; Karlsson, M.; Mcnulty, N.R.; Kallstrom, G.; Goodman, A.L.; Gordon, J.I. Creating and characterizing communities of human gut microbes in gnotobiotic mice. ISME J. 2010, 4, 1094-1098.

7. Backhed, F.; Ding, H.; Wang, T.; Hooper, L.V.; Koh, G.Y.; Nagy, A.; Semenkovich, C.F.; Gordon, J.I. The gut microbiota as an environmental factor that regulates fat storage. Proc Natl Acad. Sci. USA 2004, 101, 15718-15723.

8. Yi, P.; Li, L. The germfree murine animal: an important animal model for research on the relationship between gut microbiota and the host. Vet. Microbiol. 2012, 157, 1-7.

9. Bultman, S.J. Emerging roles of the microbiome in cancer. Carcinogenesis 2014, 35, 249-255.

10. Arthur, J.C.; Perez-Chanona, E.; Muhlbauer, M.; Tomkovich, S.; Uronis, J.M.; Fan, T.-J.; Campbell, B.J.; Abujamel, T.; Dogan, B.; Rogers, A.B. Intestinal inflammation targets cancer-inducing activity of the microbiota. Science 2012, 338, 120-123.

11. Iliev, I.D.; Funari, V.A.; Taylor, K.D.; Nguyen, Q.; Reyes, C.N.; Strom, S.P.; Brown, J.; Becker, A.A.; Fleshner, P.R.; Dubinsky, M. Interactions between commensal fungi and the C-type lectin receptor Dectin-1 influence colitis. Science 2012, 336, 1314-1317.

12. Chassaing, B.; Aitken, J.D.; Gewirtz, A.T.; Vijay-Kumar, M. Gut microbiota drives metabolic disease in immunologically altered mice. Adv. Immunol. 2012, 116, 93-112.

13. Erdman, S.E.; Poutahidis, T.; Tomczak, M.; Rogers, A.B.; Cormier, K.; Plank, B.; Horwitza, B.H.; Fox, J.G. CD4+ CD25+ regulatory $\mathrm{T}$ lymphocytes inhibit microbially induced colon cancer in Rag2-deficient mice. Am. J. Pathol. 2003, 162, 691-702.

14. Haseman, J.K.; Hailey, J.R.; Morris, R.W. Spontaneous neoplasm incidences in Fischer 344 rats and B6C3F1 mice in two-year carcinogenicity studies: A National Toxicology Program update. Toxicol. Pathol. 1998, 26, 428-441.

15. Haseman, J.K.; Huff, J.E.; Rao, G.N.; Eustis, S.L. Sources of variability in rodent carcinogenicity studies. Fundam Appl. Toxicol. 1989, 12, 793-804.

16. Rao, G.N.; Haseman, J.K.; Grumbein, S.; Crawford, D.D.; Eustis, S.L. Growth, body weight, survival, and tumor trends in F344/N rats during an eleven-year period. Toxicol. Pathol. 1990, 18, 61-70.

17. Walburg, H.E., Jr.; Cosgrove, G.E.; Upton, A.C. Influence of microbial environment on development of myeloid leukemia in X-irradiated RFM mice. Int. J. Cancer. 1968, 3, 150-154.

18. Reliene, R.; Schiestl, R.H. Differences in animal housing facilities and diet may affect study outcomes-a plea for inclusion of such information in publications. DNA Repair 2006, 5, 651-653. 
19. Fanning, S.L.; Appel, M.Y.; Berger, S.A.; Korngold, R.; Friedman, T.M. The immunological impact of genetic drift in the B10.BR congenic inbred mouse strain. J. Immunol. 2009, 183, 4261-4272.

20. Stevens, J.C.; Banks, G.T.; Festing, M.F.; Fisher, E.M. Quiet mutations in inbred strains of mice. Trends Mol. Med. 2007, 13, 512-519.

21. Rao, G.N.; Crockett, P.W. Effect of diet and housing on growth, body weight, survival and tumor incidences of B6C3F1 mice in chronic studies. Toxicol. Pathol. 2003, 31, 243-250.

22. Bleich, A.; Hansen, A.K. Time to include the gut microbiota in the hygienic standardisation of laboratory rodents. Comp. Immunol. Microbiol. Infect. Dis. 2012, 35, 81-92.

23. Yamamoto, M.L.; Maier, I.; Dang, A.T.; Berry, D.; Liu, J.; Ruegger, P.M.; Yang, J.-I.; Soto, P.A.; Presley, L.L.; Reliene, R.; et al. Intestinal bacteria modify lymphoma incidence and latency by affecting systemic inflammatory state, oxidative stress, and leukocyte genotoxicity. Cancer Res. 2013, 73, 4222-4232.

24. Saito, Y.; Suzuki, H.; Tsugawa, H.; Imaeda, H.; Matsuzaki, J.; Hirata, K.; Hosoe, N.; Nakamura, M.; Mukai, M.; Saito, H.; et al. Overexpression of miR-142-5p and miR-155 in gastric mucosa-associated lymphoid tissue (MALT) lymphoma resistant to Helicobacter pylori eradication. PLoS One 2012, 7, doi: 10.1371/journal.pone.0047396.

25. Isaacson, P.G.; Du, M.Q. MALT lymphoma: from morphology to molecules. Nat. Rev. Cancer. 2004, 4, 644-653.

26. Wotherspoon, A.C.; Ortiz-Hidalgo, C.; Falzon, M.R.; Isaacson, P.G. Helicobacter pylori-associated gastritis and primary B-cell gastric lymphoma. Lancet 1991, 338, 1175-1176.

27. Bayerdorffer, E.; Rudolph, B.; Neubauer, A.; Thiede, C.; Lehn, N.; Eidt, S.; Stolte, M.; Malt Lyphoma Study Group. Regression of primary gastric lymphoma of mucosa-associated lymphoid tissue type after cure of Helicobacter pylori infection. MALT Lymphoma Study Group. Lancet 1995, 345, 1591-1594.

28. Enno, A.; O'Rourke, J.L.; Howlett, C.R.; Jack, A.; Dixon, M.F.; Lee, A. MALToma-like lesions in the murine gastric mucosa after long-term infection with Helicobacter felis. A mouse model of Helicobacter pylori-induced gastric lymphoma. Am. J. Pathol. 1995, 147, 217-222.

29. Hirayama, F.; Takagi, S.; Kusuhara, H.; Iwao, E.; Yokoyama, Y.; Ikeda, Y. Induction of gastric ulcer and intestinal metaplasia in mongolian gerbils infected with Helicobacter pylori. J. Gastroenterol. 1996, 31, 755-757.

30. Mueller, A.; O'Rourke, J.; Grimm, J.; Guillemin, K.; Dixon, M.F.; Lee, A.; Falkow, S. Distinct gene expression profiles characterize the histopathological stages of disease in Helicobacter-induced mucosa-associated lymphoid tissue lymphoma. Proc. Natl. Acad. Sci. USA 2003, 100, 1292-1297.

31. O'Rourke, J.L. Gene expression profiling in Helicobacter-induced MALT lymphoma with reference to antigen drive and protective immunization. J. Gastroenterol. Hepatol. 2008, 23, 151-156.

32. Suzuki, A.; Kobayashi, M.; Matsuda, K.; Matsumoto, T.; Kawakubo, M.; Kumazawa, S.; Koide, N.; Miyagawa, S.; Ota, H. Induction of high endothelial venule-like vessels expressing GlcNAc6ST-1-mediated L-selectin ligand carbohydrate and mucosal addressin cell adhesion molecule 1 (MAdCAM-1) in a mouse model of "Candidatus Helicobacter heilmannii"-induced gastritis and gastric mucosa-associated lymphoid tissue (MALT) lymphoma. Helicobacter 2010, 15, 538-548. 
33. O’Rourke, J.L.; Dixon, M.F.; Jack, A.; Enno, A.; Lee, A. Gastric B-cell mucosa-associated lymphoid tissue (MALT) lymphoma in an animal model of "Helicobacter heilmannii" infection. J. Pathol. 2004, 203, 896-903.

34. Nakamura, M.; Murayama, S.Y.; Serizawa, H.; Sekiya, Y.; Eguchi, M.; Takahashi, S.; Nishikawa, K.; Takahashi, T.; Matsumoto, T.; Yamada, H.; et al. "Candidatus Helicobacter heilmannii" from a cynomolgus monkey induces gastric mucosa-associated lymphoid tissue lymphomas in C57BL/6 mice. Infect. Immun. 2007, 75, 1214-1222.

35. Suarez, F.; Lortholary, O.; Hermine, O.; Lecuit, M. Infection-associated lymphomas derived from marginal zone B cells: a model of antigen-driven lymphoproliferation. Blood 2006, 107, 3034-3044.

36. Gold, J.S.; Bayar, S.; Salem, R.R. Association of Streptococcus bovis bacteremia with colonic neoplasia and extracolonic malignancy. Arch. Surg. 2004, 139, 760-765.

37. Hanahan, D.; Weinberg, R.A. The hallmarks of cancer. Cell 2000, 100, 57-70.

38. Newman, J.V.; Kosaka, T.; Sheppard, B.J.; Fox, J.G.; Schauer, D.B. Bacterial infection promotes colon tumorigenesis in Apc(Min/+) mice. J. Infect. Dis. 2001, 184, 227-230.

39. Wu, S.; Rhee, K.J.; Albesiano, E.; Rabizadeh, S.; Wu, X.; Yen, H.-R.; Huso, D.L.; Brancati, F.L.; Wick, E.; McAllister, F.; et al. A human colonic commensal promotes colon tumorigenesis via activation of T helper type $17 \mathrm{~T}$ cell responses. Nat. Med. 2009, 15, 1016-1022.

40. Diwan, B.A.; Ward, J.M.; Ramljak, D.; Anderson, L.M. Promotion by Helicobacter hepaticus-induced hepatitis of hepatic tumors initiated by $\mathrm{N}$-nitrosodimethylamine in male A/JCr mice. Toxicol. Pathol. 1997, 25, 597-605.

41. Barlow, C.; Hirotsune, S.; Paylor, R.; Liyanage, M.; Eckhaus, M.; Collins, F.; Shiloh, Y.; Crawley, J.N.; Ried, T.; Tagle, D.; et al. Atm-deficient mice: a paradigm of ataxia telangiectasia. Cell 1996, 86, 159-171.

42. Reliene, R.; Schiestl, R.H. Antioxidant N-acetyl cysteine reduces incidence and multiplicity of lymphoma in Atm deficient mice. DNA Repair 2006, 5, 852-859.

43. Fujiwara, D.; Wei, B.; Presley, L.L.; Brewer, S.; McPherson, M.; Lewinki, M.A.; Borneman, J.; Braun, J. Systemic control of plasmacytoid dendritic cells by CD8+ T cells and commensal microbiota. J. Immunol. 2008, 180, 5843-5852.

44. Artis, D. Epithelial-cell recognition of commensal bacteria and maintenance of immune homeostasis in the gut. Nat. Rev. Immunol. 2008, 8, 411-420.

45. MacDonald, T.T.; Gordon, J.N. Bacterial regulation of intestinal immune responses. Gastroenterol. Clin. North Am. 2005, 34, 401-412, vii-viii.

46. Reddy, B.S.; Mangat, S.; Weisburger, J.H.; Wynder, E.L. Effect of high-risk diets for colon carcinogenesis on intestinal mucosal and bacterial beta-glucuronidase activity in F344 rats. Cancer Res. 1977, 37, 3533-3536.

47. Takada, H.; Hirooka, T.; Hiramatsu, Y.; Yamamoto, M. Effect of beta-glucuronidase inhibitor on azoxymethane-induced colonic carcinogenesis in rats. Cancer Res. 1982, 42, 331-334.

48. Knasmuller, S.; Steinkellner, H.; Hirschl, A.M.; Rabot, S.; Nobis, E.C.; Kassie, F. Impact of bacteria in dairy products and of the intestinal microflora on the genotoxic and carcinogenic effects of heterocyclic aromatic amines. Mutat. Res. 2001, 480-481, 129-138. 
49. Kassie, F.; Rabot, S.; Kundi, M.; Chabicovsky, M.; Qin, H.M.; Knasmuller, S. Intestinal microflora plays a crucial role in the genotoxicity of the cooked food mutagen 2-amino-3-methylimidazo [4,5-f]quinoline. Carcinogenesis 2001, 22, 1721-1725.

50. Hayatsu, H.; Hayatsu, T. Suppressing effect of Lactobacillus casei administration on the urinary mutagenicity arising from ingestion of fried ground beef in the human. Cancer Lett. 1993, 73, 173-179.

51. Kullisaar, T.; Songisepp, E.; Mikelsaar, M.; Zilmer, K.; Vihalemm, T.; Zilmer, M. Antioxidative probiotic fermented goats' milk decreases oxidative stress-mediated atherogenicity in human subjects. Br. J. Nutr. 2003, 90, 449-456.

52. Blaser, M.J.; Atherton, J.C. Helicobacter pylori persistence: biology and disease. J. Clin. Invest. 2004, 113, 321-333.

53. Arabski, M.; Klupinska, G.; Chojnacki, J.; Kazmierczak, P.; Wisniewska-Jarosinska, M.; Drzewoski, J.; Blasiak, J. DNA damage and repair in Helicobacter pylori-infected gastric mucosa cells. Mutat. Res. 2005, 570, 129-135.

54. Smoot, D.T.; Elliott, T.B.; Verspaget, H.W.; Jones, D.; Allen, C.R.; Vernon, K.G.; Bremner, T.; Kidd, C.R.; Kim, K.S.; Groupman, J.D.; et al. Influence of Helicobacter pylori on reactive oxygen-induced gastric epithelial cell injury. Carcinogenesis 2000, 21, 2091-2095.

55. Klinder, A.; Forster, A.,.; Caderni, G.; Femia, A.P.; Pool-Zobel, B.L. Fecal water genotoxicity is predictive of tumor-preventive activities by inulin-like oligofructoses, probiotics (Lactobacillus rhamnosus and Bifidobacterium lactis), and their synbiotic combination. Nutr. Cancer 2004, 49 , 144-155.

56. Vieira, J.M.; Seabra, S.H.; Vallim, D.C.; Americo, M.A.; Fracallanza, S.E.L.; Vommaro, R.C.; Domingues, R.M.C.P. Bacteroides fragilis induce necrosis on mice peritoneal macrophages: In vitro and in vivo assays. Biochem. Biophys. Res. Commun. 2009, 387, 627-632.

57. Kumar, A.; Wu, H.; Collier-Hyams, L.S.; Hansen, J.M.; Li, T.; Yamoah, K.; Pan, Z.-Q.; Jones, D.P.; Neish, A.S. Commensal bacteria modulate cullin-dependent signaling via generation of reactive oxygen species. EMBO J. 2007, 26, 4457-4466.

58. Ames, B.N.; Shigenaga, M.K.; Hagen, T.M. Oxidants, antioxidants, and the degenerative diseases of aging. Proc. Natl. Acad. Sci. USA 1993, 90, 7915-7922.

59. Cerutti, P.; Ghosh, R.; Oya, Y.; Amstad, P. The role of the cellular antioxidant defense in oxidant carcinogenesis. Environ. Health Perspect. 1994, 102, 123-129.

60. Coussens, L.M.; Werb, Z. Inflammation and cancer. Nature 2002, 420, 860-867.

61. Banks, P.M. Gastrointestinal lymphoproliferative disorders. Histopathology 2007, 50, $42-54$.

62. Bende, R.J.; Aarts, W.M.; Riedl, R.G.; de Jong, D.; Pals, S.T.; van Noesel, C.J. Among B cell non-Hodgkin's lymphomas, MALT lymphomas express a unique antibody repertoire with frequent rheumatoid factor reactivity. J. Exp. Med. 2005, 201, 1229-1241.

63. Shanahan, F. Nutrient tasting and signaling mechanisms in the gut V. Mechanisms of immunologic sensation of intestinal contents. Am. J. Physiol. Gastrointest Liver Physiol. 2000, 278, 191-196.

64. Arimochi, H.; Kinouchi, T.; Kataoka, K.; Kuwahara, T.; Ohnishi, Y. Effect of intestinal bacteria on formation of azoxymethane-induced aberrant crypt foci in the rat colon. Biochem. Biophys. Res. Commun. 1997, 238, 753-757. 
65. Hirayama, K.; Rafter, J. The role of probiotic bacteria in cancer prevention. Microbes Infect. 2000, 2, 681-686.

66. Cebra, J.J. Influences of microbiota on intestinal immune system development. Am. J. Clin. Nutr. 1999, 69, 1046-1051.

67. Hooper, L.V.; Midtvedt, T.; Gordon, J.I. How host-microbial interactions shape the nutrient environment of the mammalian intestine. Annu. Rev. Nutr. 2002, 22, 283-307.

68. Hooper, L.V.; Gordon, J.I. Commensal host-bacterial relationships in the gut. Science 2001, 292, 1115-1118.

69. Wei, B.; Su, T.T.; Dalwadi, H.; Stephan, R.P.; Fujiwara, D.; Huang, T.T.; Brewer, S.; Chen, L.; Arditi, M.; Borneman, J.; et al. Resident enteric microbiota and CD8+ T cells shape the abundance of marginal zone B cells. Eur. J. Immunol. 2008, 38, 3411-3425.

70. Wei, B.; Wingender, G.; Fujiwara, D.; Chen, D.Y.; McPherson, M.; Brewer, S.; Borneman, J.; Kronenberg, M.; Braun, J. Commensal microbiota and CD8+ T cells shape the formation of invariant NKT cells. J. Immunol. 2010, 184, 1218-1226.

71. Huang, T.; Wei, B.; Velazquez, P.; Borneman, J.; Braun, J. Commensal microbiota alter the abundance and TCR responsiveness of splenic naive CD4+ T lymphocytes. Clin. Immunol. 2005, $117,221-230$.

72. Gaboriau-Routhiau, V.; Rakotobe, S.; Lecuyer, E.; Mulder, I.; Lan, A.; Bridonneau, C.; Rochet,V.; Pisi, A.; De Paepe, M.; Brandi, G.; et al. The key role of segmented filamentous bacteria in the coordinated maturation of gut helper T cell responses. Immunity 2009, 31, 677-689.

73. Mazmanian, S.K.; Liu, C.H.; Tzianabos, A.O.; Kasper, D.L. An immunomodulatory molecule of symbiotic bacteria directs maturation of the host immune system. Cell 2005, 122, 107-118.

74. Sonnenburg, J.L.; Chen, C.T.; Gordon, J.I. Genomic and metabolic studies of the impact of probiotics on a model gut symbiont and host. PLoS Biol. 2006, 4, doi:10.1371/journal.pbio.0040413.

75. Vannucci, L.; Stepankova, R.; Kozakova, H.; Fiserova, A.; Rossmann, P.; Tlaskalova-Hogenova, H. Colorectal carcinogenesis in germ-free and conventionally reared rats: different intestinal environments affect the systemic immunity. Int. J. Oncol. 2008, 32, 609-617.

76. Ishikawa, H.; Akedo, I.; Otani, T.; Takeyama, I.; Ishiguro, S.; Miyaoka, E.; Sobue, T.; Kakizoe, T. Randomized trial of dietary fiber and Lactobacillus casei administration for prevention of colorectal tumors. Int. J. Cancer. 2005, 116, 762-767.

77. Kim, J.E.; Kim, J.Y.; Lee, K.W.; Lee, H.J. Cancer chemopreventive effects of lactic acid bacteria. J. Microbiol. Biotechnol. 2007, 17, 1227-1235.

78. Kingma, S.D.; Li, N.; Sun, F.; Valladares, R.B.; Neu, J.; Lorca, G.L. Lactobacillus johnsonii N6.2 stimulates the innate immune response through Toll-like receptor 9 in Caco-2 cells and increases intestinal crypt Paneth cell number in biobreeding diabetes-prone rats. J. Nutr. 2011, 141, 1023-1028.

79. Valladares, R.; Sankar, D.; Li, N.; Williams, E.; Lai, K.-K.; Abdelgeliel, A.S.; Gonzalez, C.F.; Wasserfall, C.H.; Larkin, J., III; Schatz, D.; et al. Lactobacillus johnsonii N6.2 mitigates the development of type 1 diabetes in BB-DP rats. PLoS One 5, doi:10.1371/journal.pone.0010507.

80. Matsuzaki, T. Immunomodulation by treatment with Lactobacillus casei strain Shirota. Int. J. Food Microbiol. 1998, 41, 133-140.

81. Kato, I.; Endo, K.; Yokokura, T. Effects of oral administration of Lactobacillus casei on antitumor responses induced by tumor resection in mice. Int. J. Immunopharmacol. 1994, 16, 29-36. 
82. Kato, I.; Yokokura, T.; Mutai, M. Macrophage activation by Lactobacillus casei in mice. Microbiol. Immunol. 1983, 27, 611-618.

83. Rafter, J. Probiotics and colon cancer. Best Pract Res Clin Gastroenterol. 2003, 17, 849-859.

84. Smith, P.M.; Howitt, M.R.; Panikov, N.; Michaud, M.; Gallini, C.A.; Bohlooly-Y, M.; Glickman, J.N.; Garrett, W.S. The microbial metabolites, short-chain fatty acids, regulate colonic Treg cell homeostasis. Science 2013, 341, 569-573.

85. Arpaia, N.; Campbell, C.; Fan, X.; Dikiy, S.; van der Veeken, J.; deRoos, P.; Liu, H.; Cross, J.R.; Pfeffer, K.; Coffer, P.J.; et al. Metabolites produced by commensal bacteria promote peripheral regulatory T-cell generation. Nature 2013, 504, 451-455.

86. Ames, B.N.; Gold, L.S. Too many rodent carcinogens: mitogenesis increases mutagenesis. Science 1990, 249, 970-971.

87. Cohen, S.M.; Ellwein, L.B. Cell proliferation in carcinogenesis. Science 1990, 249, 1007-1011.

88. Shaffer, A.L.; Rosenwald, A.; Staudt, L.M. Lymphoid malignancies: the dark side of B-cell differentiation. Nat. Rev. Immunol. 2002, 2, 920-932.

89. Pasqualucci, L.; Neumeister, P.; Goossens, T.; Nanjangud, G.; Chaganti, R.S.K.; Kuppers, R.; Dalla-Favera, R. Hypermutation of multiple proto-oncogenes in B-cell diffuse large-cell lymphomas. Nature 2001, 412, 341-346.

90. Oliver, A.M.; Martin, F.; Kearney, J.F. IgMhighCD21high lymphocytes enriched in the splenic marginal zone generate effector cells more rapidly than the bulk of follicular B cells. J. Immunol. 1999, 162, 7198-7207.

91. Kullisaar, T.; Zilmer, M.; Mikelsaar, M.; Vihalemm, T.; Annuk, H.; Kairane, C.; Kilk, A. Two antioxidative lactobacilli strains as promising probiotics. Int. J. Food Microbiol. 2002, 72, 215-224.

92. Federico, A.; Morgillo, F.; Tuccillo, C.; Ciardiello, F.; Loguercio, C. Chronic inflammation and oxidative stress in human carcinogenesis. Int. J. Cancer. 2007, 121, 2381-2386.

93. Epeldegui, M.; Widney, D.P.; Martinez-Maza, O. Pathogenesis of AIDS lymphoma: role of oncogenic viruses and B cell activation-associated molecular lesions. Curr. Opin. Oncol. 2006, $18,444-448$.

94. Illes, A.; Varoczy, L.; Papp, G.; Wilson, P.C.; Alex, P.; Jonsson, R.; Kovacs, T.; Konttinen, Y.T.; Zeher, M.; Nakken, B.; Szodoray, P. Aspects of B-cell non-Hodgkin's lymphoma development: a transition from immune-reactivity to malignancy. Scand. J. Immunol. 2009, 69, 387-400.

95. Al-Saleem, T.; Al-Mondhiry, H. Immunoproliferative small intestinal disease (IPSID): a model for mature B-cell neoplasms. Blood 2005, 105, 2274-2280.

96. Lecuit, M.; Abachin, E.; Martin, A.; Poyart, C.; Pochart, P.; Suarez, F.; Bengoufa, D.; Feuillard, J.; Lavergne, A.; Gordon, J.I.; et al. Immunoproliferative small intestinal disease associated with Campylobacter jejuni. N. Engl. J. Med. 2004, 350, 239-248.

97. Ferreri, A.J.; Guidoboni, M.; Ponzoni, M.; de Conciliis, C.; Dell'Oro, S.; Fleischhauer, K.; Caggiari, L.; Lettini, A.A.; Clin, E.D.; Leri, R.; et al. Evidence for an association between Chlamydia psittaci and ocular adnexal lymphomas. J. Natl. Cancer Inst. 2004, 96, 586-594.

(C) 2014 by the authors; licensee MDPI, Basel, Switzerland. This article is an open access article distributed under the terms and conditions of the Creative Commons Attribution license (http://creativecommons.org/licenses/by/3.0/). 